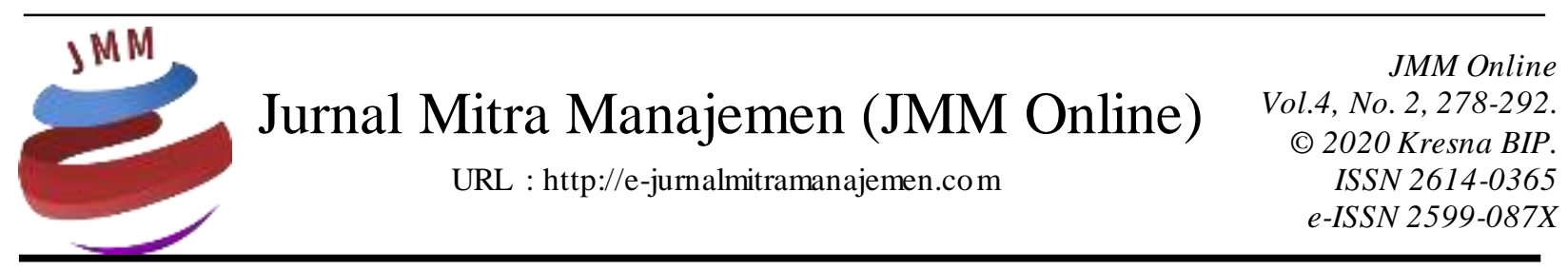

\title{
PENGARUH KOMITMEN ORGANISASI, INTENSITAS MORAL DAN SOSIALISASI ANTISIPATIF TERHADAP TINDAKAN WHISTLEBLOWING
}

\author{
Maulid Ulil Barkah 1), Annisa Nurbaiti 2) \\ Universitas Telkom
}

INFORMASI ARTIKEL

Dikirim : 14 Februari 2020

Revisi pertama : 17 Februari 2020

Diterima : 19 Februari 2020

Tersedia online : 27 Februari 2020

Kata Kunci : Tindakan Whistleblowing, Komitmen Organisasi, Intensitas Moral, Sosialisasi Antisipatif

Email : ulilmaulidb@gmail.com ${ }^{1}$, annisanurbaiti@telkomuniversity.ac.id ${ }^{2)}$

\section{ABSTRAK}

Whistleblowing merupakan cara yang efektif dalam pelaporan kasus kecurangan, namun dalam praktiknya terdapat banyak resiko yang harus di terima oleh pelaku whistleblowing yang menyebabkan gagal dilakukannya whistleblowing tersebut.

Penelitian ini bertujuan untuk memperoleh bukti empiris mengenai pengaruh komitmen organisasi, intensitas moral, dan sosialisasi antisipatif terhadap tindakan whistleblowing. Objek penelitian yang digunakan adalah alumni S1 Akuntansi Telkom University yang lulus pada Tahun 2017-2019. Metode pengumpulan data dengan menyebarkan kuisioner kepada alumni S1 Akuntansi Telkom University. Pengumpulan sampel menggunakan teknik insidental sampling, jumalah sampel dari penelitian sebanyak 56 responden. Teknik analisis data menggunakan analisis regresi linier berganda.

Dari hasil pengujian menggunakan software SPSS 25, didapatkan hasil secara simultan variabel independen yang terdiri dari komitmen organisasi, intensitas moral, dan sosialisasi antisipatif berpengaruh simultan terhadap tindakan whistleblowing. Untuk pengujian secara parsial menunjukan bahwa variabel komitmen organisasi dan sosialisasi antisipatif tidak berpengaruh parsial terhadap tindakan whistleblowing, kemudian variabel intensitas moral berpengaruh parsial terhadap tindakan whistleblowing. 


\section{PENDAHULUAN \\ Latar Belakang}

Kasus kecurangan dalam dunia akuntansi telah menyebabkan lunturnya kepercayaan publik terhadap profesi akuntan yang seharusnya menjunjung tinggi nilai independensi dan profesionalitas. Menurut Sofyanty (2013) kecurangan atau fraud merupakan tindakan yang dilakukan karena adanya kesempatan, tekanan, konfrontasi bahkan pembenaran atas tindakan yang dilakukan oleh seseorang. Maraknya kasus kecurangan laporan keuangan, penyalahgunaan aset, bahkan korupsi menjadi kasus yang banyak terjadi di Indonesia. Maraknya kasus kecurangan laporan keuangan, penyalahgunaan aset, bahkan korupsi menjadi kasus yang banyak terjadi di Indonesia. Sugianto dkk (2011) menyatakan bahwa penyalahgunaan keahlian dalam membuat informasi akuntansi yang menyesatkan dan tidak benar untuk meraup keuntungan pribadi, telah menimbulkan kerugian.

Salah satu cara pengungkapan kecurangan sehingga dapat mengembalikan kepercayaan masyarakat terhadap profesi akunting adalah dengan cara yaitu whistleblowing. Menurut Kareshastuti (2016) Whistleblowing adalah pelaporan yang dilakukan oleh anggota organisasi baik yang aktif maupun non-aktif mengenai pelanggaran, tindakan ilegal, atau tidak bermoral kepada pihak di dalam maupun di luar organisasi. Menurut Tuanakotta (2010) dalam Sofyanti (2019) menjadi whistleblower merupakan tindakan yang beresiko karena terdapat ancaman fisik dan psikis baik secara langsung maupun tidak langsung dari pihak tertentu yang mengakibatkan whistleblower merasa takut dan dipaksa untuk melakukan atau tidak melakukan sesuatu yang berkenaan dengan kesaksiannya dalam suatu kasus. Hal tersebut dialami oleh Komisaris Jendral Susno Duadji, dimana ia justru dijadikan tersangka atas pasal pencemaran nama baik dan pelanggaran disiplin sebagai anggota Polri. Atas kasus tersebut pemerintah kemudian bekerjasama denga beberapa pihak untuk menjamin perlindungan keamanan bagi seorang whistleblower. Namun menurut ACFE (Survai Fraud Indonesia, 2016) yang menyatakan bahwa pencegahan fraud yang paling efektif adalah melalui mekanisme whistleblowing hotline.

Maka dari itu pelapora kecurangan dengan melakukan whistleblowing merupakan cara yang efektif karena dapat dilakukan oleh siapa saja yang mengetahui kecurangan yang terjadi di organisasi serta sudah ada pedoman sistem pelaporan pelanggaran nya, namun dalam proses pelaksanaan nya terdapat resiko yang bersifat mengancam whistleblower baik ancaman fisik maupun psikis.

\section{Rumusan Masalah}

Berdasarkan perumusan masalah mengenai faktor-fator yang mempengaruhi tindakan whistleblowing, maka dapat dirumuskan permasalahan sebagai berikut :

1. Bagaimana komitmen organisasi, intensitas moral, sosialisasi antisipatif dan tindakan whistleblowing pada alumni S1 Akuntansi Telkom University?

2. Bagaimana komitmen organisasi, intensitas moral, dan sosialisasi antisipatif berpengaruh secara simultan terhadap tindakan whistleblowing pada alumni S1 Akuntansi Telkom University?

3. Bagaimana komitmen organisasi berpengaruh secara parsial terhadap tindakan whistleblowing pada alumni S1 Akuntansi Telkom University? 
4. Bagaimana intensitas moral berpengaruh secara parsial terhadap tindakan whistleblowing pada alumni S1 Akuntansi Telkom University?

5. Bagaimana sosialisasi antisipatif berpengaruh secara parsial terhadap tindakan whistleblowing pada alumni S1 Akuntansi Telkom University?

\section{Tujuan Penelitian}

Berdasarkan perumusan masalah yang telah diuraikan sebelumnya, maka dapat disimpulkan bahwa tujuan peleitian ini antara lain :

1. Untuk mengetahui bagaimana komitmen organisasi, intensitas moral, sosialisasi antisipatif, dan tindakan whistleblowing pada alumni S1 akuntansi Telkom University.

2. Untuk mengetahui pengaruh koitmen organisasi, intensitas moral, dan sosialisasi antisipatif secara simultan terhadap tindakan whistleblowing pada alumni S1 Akuntansi Telkom University.

3. Untuk mengetahui pengaruh komitmen organisasi secara parsial terhadap tindakan whistleblowing pada alumni S1 Akuntansi Telkom University.

4. Untuk mengetahui pengaruh intensitas moral secara parsial terhadap tindakan whistleblowing pada alumni S1 Akuntansi Telkom University.

5. Untuk mengetahui pengaruh sosialisasi antisipatif secara parsial terhadap tindakan whistleblowing pada alumni S1 Akuntansi Telkom University.

\section{KAJIAN PUSTAKA \\ Prosocial Organizational Behavior Theory}

Sugianto (2011) Mendefinisikan prosocial organizational behavior theory sebagai perilaku atau tindakan yang dilakukan oleh anggota sebuah organisasi terhadap individu, kelompok atau organisasi yang ditujukan untuk meningkatkan kesejahteraan individu, kelompok, atau organisasi tersebut. Bakri (2014) Menyebutkan bahwa whistleblowing dapat dipandang sebagai perilaku prososial karena secara umum perilaku tersebut akan memberikan manfaat bagi orang lain disamping juga bermanfaat bagi whistleblower itu sendiri.

\section{Theory of Planned Behavior}

Dalam Kareshastuti (2014) Theory of Planned Behavior bertujuan untuk memprediksi dan memahami dampak niat berprilaku, mengidentifikasi strategi untuk mengubah perilaku serta menjelaskan perilaku nyata manusia, dalam hubungan ini Theory of Planned Behavior diasumsikan bahwa manusia yang bersifat rasional akan menggunakan informasi yang ada secara sistematik kemudian memahami dampak perilakunya sebelum memutuskan untuk mewujudkan perilaku tersebut.

\section{Tindakan Whistleblowing}

Menurut Gani (2010) mendefinisikan tindakan whistleblowing sebagai suatu pengungkapan oleh karyawan mengenai suatu informasi yang diyakini mengandung pelanggaran hukum, peraturan, pedoman praktis atau pernyataan profesional, atau berkaitan dengan kesalahan prosedur, korupsi, penyalahgunaan wewenang atau membahayakan publik dan keselamatan tempat kerja. 


\section{Komitmen Organisasi}

Menurut Sofyanty (2019) menyebutkan bahwa komitmen organisasi merupakan dimensi perilaku penting yang dapat digunakan untuk menilai kecenderungan karyawan untuk bertahan sebagai anggota organisasi.

\section{Intensitas Moral}

Setiawati (2016) Berpendapat bahwa intensitas moral adalah sesuatu yang berkaitan dengan isu-isu moral yang akan berpengaruh pada penilaian etika seseorang dan niat untuk seseorang melakukan suatu tindakan.

\section{Sosialisasi Antisipatif}

Kareshastuti (2014) Mengartikan sosialisasi antisipatif merupakan hasil dari seluruh pembelajaran yang dilakukan oleh seorang individu sebelum hari pertama dia bekerja.

\section{Gambar 1. Kerangka Pemikiran}

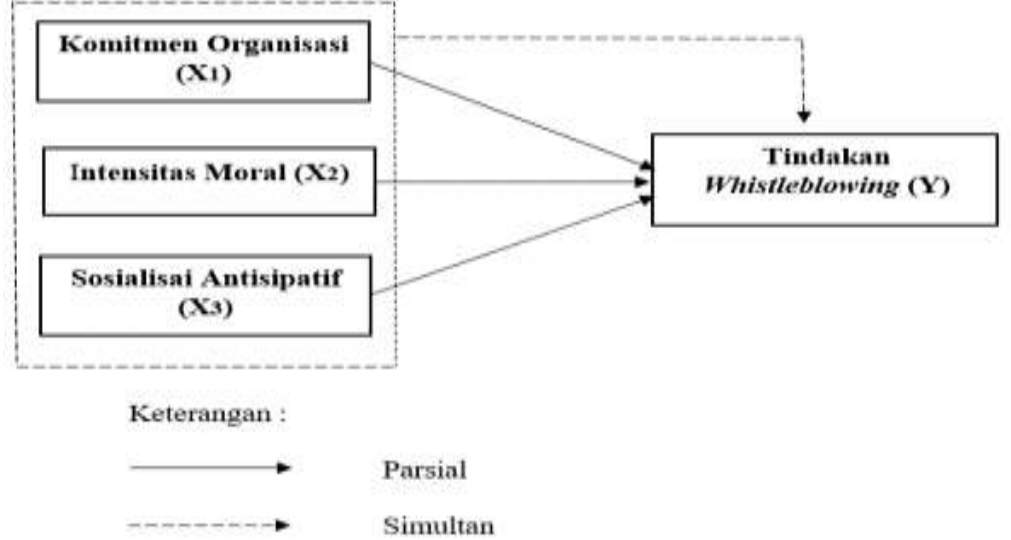

\section{Hipotesis Penelitian}

$\mathrm{H}_{1}$ :Komitmen Organisasi, Intensitas moral, dan Sosialisasi Antisipatif berpengaruh secara simultanterhadap tindakan Whistleblowing pada alumni S1 Akuntansi Telkom University yang Lulus Pada Tahun 2017-2019.

$\mathrm{H}_{2}$ :Komitmen Organisasi berpengaruh secara parsial terhadap Tindakan Whistleblowing pada Alumni S1 Akuntansi Telkom University yang Lulus Pada Tahun 2017-2019.

$\mathrm{H}_{3}$ :Intensitas Moral berpengaruh secara parsial terhadap Tindakan Whistleblowing pada Alumni S1 Akuntansi Telkom University yang Lulus Pada Tahun 2017-2019.

$\mathrm{H}_{4}$ :Sosialisasi Antisipatif berpengaruh secara parsial terhadap Tindakan Whistleblowing pada Alumni S1 Akuntansi Telkom University yang Lulus Pada Tahun 2017-2019. 


\section{METODE PENELITIAN \\ Jenis Penelitian}

Metode yang digunakan dalam penelitian ini berjnis kuantitatif dengan tujuan penelitian deskriptif yaitu mendeskripsikan pengaruh komitmen organisasi, intensitas mroal dan sosialisasi antisipatif terhadap tindakan whistleblowing.

\section{Tempat, Waktu, dan Subjek Penelitian}

Tempat penelitian bersifat dalam jaringan karena penyebaran kuisioner dilakukan secara online. Waktu peneltian berjenis time series karena data yang digunakan dalam penelitian ini adalah data dalam interval waktu tertentu yaitu dari tahun 2017 sampai dengan 2019. Subjek penelitian berjenis individu yaitu alumni S1 Akuntansi Telkom University yang lulus pada tahun 2017, 2018, dan 2019.

\section{Teknik Pengumpulan Data}

Penulis melakukan penyebaran kuisioner untuk mendapatkan data primer langsung dari pihak-pihak yang berkaitan denga penelitian yang dilakukan, dalam hal ini adalah alumni S1 Akuntansi Telkom University. Pengumpulan data sekunder dalam penelitian ini melalui sumber data lain yaitu refrensi dari jurnal, artikel, dan hasil dari penelitian terdahulu yang sesuai dengan topik penelitian.

\section{Teknik Analisis Data}

1. Uji Validitas \& Reliabilitas

2. Analisis Statistik Deskriptif

3. Uji Normalitas

4. Uji Multikolinearitas

5. Uji Heteroskedastisitas
6. Analisis Regresi Linier Berganda

7. Analisis Koefisien Korelasi

8. Koefisien Determinasi Berganda $\left(\mathrm{R}^{2}\right)$

9. Uji Simultan $(\mathrm{F})$

10. Uji Parsial (T)

\section{HASIL PENELITIAN DAN PEMBAHASAN}

\section{Uji Validitas}

Tabel 1. Uji Validitas

\begin{tabular}{|l|l|l|l|l|}
\hline No. & Variabel & r hitung & r tabel (sig. 0,05) & Keterangan \\
\hline & \multicolumn{4}{|c|}{ Tindakan Whistleblowing } \\
\hline 1. & SRS 1 & 0.506 & 0.2632 & Valid \\
\hline 2. & TJ 1 & 0.490 & 0.2632 & Valid \\
\hline 3. & RIS 1 & 0.300 & 0.2632 & Valid \\
\hline 4. & WI 1 & 0.536 & 0.2632 & Valid \\
\hline 5. & SRS 2 & 0.513 & 0.2632 & Valid \\
\hline 6. & TJ 2 & 0.582 & 0.2632 & Valid \\
\hline 7. & RIS 2 & 0.372 & 0.2632 & Valid \\
\hline 8. & WI 2 & 0.723 & 0.2632 & Valid \\
\hline 9. & SRS 3 & 0.298 & 0.2632 & Valid \\
\hline 10. & TJ 3 & 0.689 & 0.2632 & Valid \\
\hline 11. & RIS 3 & 0.571 & 0.2632 & Valid \\
\hline
\end{tabular}


Lanjutan Tabel 1. Uji Validitas

\begin{tabular}{|c|c|c|c|c|}
\hline 12. & WI 3 & 0.667 & 0.2632 & Valid \\
\hline & \multicolumn{4}{|c|}{ Komitmen Organisasi } \\
\hline 13. & KO 1 & 0.671 & 0.2632 & Valid \\
\hline 14. & $\mathrm{KO} 2$ & 0.658 & 0.2632 & Valid \\
\hline 15. & $\mathrm{KO} 3$ & 0.513 & 0.2632 & Valid \\
\hline 16. & $\mathrm{KO} 4$ & 0.610 & 0.2632 & Valid \\
\hline 17. & KO 5 & 0.645 & 0.2632 & Valid \\
\hline 18. & $\mathrm{KO} 6$ & 0.631 & 0.2632 & Valid \\
\hline 19. & $\mathrm{KO} 7$ & 0.613 & 0.2632 & Valid \\
\hline 20. & $\mathrm{KO} 8$ & 0.695 & 0.2632 & Valid \\
\hline \multirow[t]{2}{*}{21.} & KO 9 & \begin{tabular}{|l|}
0.613 \\
\end{tabular} & 0.2632 & Valid \\
\hline & \multicolumn{4}{|c|}{ Intensitas Moral } \\
\hline 22. & IM 1 & 0.710 & 0.2632 & Valid \\
\hline 23. & IM 2 & 0.582 & 0.2632 & Valid \\
\hline 24. & IM 3 & 0.725 & 0.2632 & Valid \\
\hline 25. & IM 4 & 0.632 & 0.2632 & Valid \\
\hline \multirow[t]{2}{*}{26.} & IM 5 & 0.434 & 0.2632 & Valid \\
\hline & \multicolumn{4}{|c|}{ Sosialisasi Antisipatif } \\
\hline 27. & $\mathrm{M}$ & 0.563 & 0.2632 & Valid \\
\hline 28. & $\mathrm{M}$ & 0.582 & 0.2632 & Valid \\
\hline 29. & $\mathrm{M}$ & 0.499 & 0.2632 & Valid \\
\hline 30. & $\mathrm{M}$ & \begin{tabular}{|l|l|}
0.533 \\
\end{tabular} & 0.2632 & Valid \\
\hline 31. & $\mathrm{D}$ & 0.695 & 0.2632 & Valid \\
\hline 32. & $\mathrm{D}$ & \begin{tabular}{|l|}
0.631 \\
\end{tabular} & 0.2632 & Valid \\
\hline 33. & CB & 0.621 & 0.2632 & Valid \\
\hline 34. & CB & 0.456 & 0.2632 & Valid \\
\hline 35. & $\mathrm{CB}$ & 0.448 & 0.2632 & Valid \\
\hline 36. & $\mathrm{R}$ & 0.524 & 0.2632 & Valid \\
\hline 37. & $\mathrm{R}$ & 0.332 & 0.2632 & Valid \\
\hline
\end{tabular}

Sumber : Hasil Penelitian, diolah (2020)

Nilai $r$ tabel diketahui yaitu $0.2632<\mathrm{r}$ tabel dengan nilai positif, maka kesimpulan dari uji validitas yang dilakukan adalah butir-butir pertanyaan yang ada pada masing masing variabel dinyatakan valid dan tidak ada butir pertanyaan yang perlu di drop out.

\section{Uji Reliabilitas}

Tabel 2. Hasil Uji Reliabilitas

\begin{tabular}{|l|l|l|l|}
\hline Variabel & $\begin{array}{l}\text { Jumlah Butir } \\
\text { Pertanyaan }\end{array}$ & $\begin{array}{l}\text { Cronbach } \\
\text { Alpha }\end{array}$ & Keterangan \\
\hline Tindakan Whistleblowing & 12 pertanyaan & 0.754 & Reliabel \\
\hline Komitmen Organisasi & 9 pertanyaan & 0.805 & Reliabel \\
\hline
\end{tabular}


Lanjutan Tabel 2. Hasil Uji Reliabilitas

\begin{tabular}{|l|l|l|l|}
\hline Intensitas Moral & 5 pertanyaan & 0.601 & Reliabel \\
\hline Sosialisasi Antisipatif & 10 pertanyaan & 0.745 & Reliabel \\
\hline
\end{tabular}

Sumber : Hasil Penelitian, diolah (2020)

Dari hasil uji reliabilitas dapat dilihat bahwa nilai cronbach alpha dari variabel tindakan whistleblowing sebesar 0.754, kemudian variabel komitmen organisasi sebesar 0.805, selanjutnya variabel intensitas moral sebesar 0.601, dan variabel sosialisasi antisipatif sebesar 0.745 , maka dapat disimpulkan bahwa semua pertanyaan dari setiap variabel dinyatakan reliabel dikarnakan nilai cronbach alpha dari tiap variabel lebih besar dari 0.6.

\section{Analisis Statistik Deskriptif}

Tabel 3. Tanggapan Responden Terhadap Variabel Tindakan Whistleblowing

\begin{tabular}{|c|c|c|c|c|c|c|c|c|}
\hline \multirow{2}{*}{$\begin{array}{l}\text { No. } \\
\text { item }\end{array}$} & STS & $\mathrm{TS}$ & $\mathrm{N}$ & $S$ & SS & \multirow{2}{*}{ Jumlah } & Skor & \multirow{2}{*}{$\begin{array}{l}\text { Skor } \\
\text { Ideal }\end{array}$} \\
\hline & 1 & 2 & 3 & 4 & 5 & & Total & \\
\hline \multirow{2}{*}{1} & 0 & 1 & 10 & 28 & 17 & 56 & 229 & \multirow{2}{*}{280} \\
\hline & $0 \%$ & $1.8 \%$ & $17,9 \%$ & $50 \%$ & $30,4 \%$ & $100 \%$ & $81,7 \%$ & \\
\hline \multirow{2}{*}{2} & 0 & 5 & 5 & 28 & 18 & 56 & 227 & \multirow{2}{*}{280} \\
\hline & $0 \%$ & $8,9 \%$ & $8,9 \%$ & $50 \%$ & $32,1 \%$ & $100 \%$ & $81.07 \%$ & \\
\hline \multirow{2}{*}{3} & 1 & 2 & 15 & 26 & 12 & 56 & 214 & \multirow{2}{*}{280} \\
\hline & $1.8 \%$ & $3,6 \%$ & $26,8 \%$ & $46,4 \%$ & $21,4 \%$ & $100 \%$ & $76,4 \%$ & \\
\hline \multirow{2}{*}{4} & 0 & 3 & 11 & 28 & 14 & 56 & 221 & \multirow{2}{*}{280} \\
\hline & $0 \%$ & $5,4 \%$ & $19,6 \%$ & $50 \%$ & $25 \%$ & $100 \%$ & $79 \%$ & \\
\hline \multirow{2}{*}{5} & 0 & 1 & 18 & 29 & 8 & 56 & 212 & \multirow{2}{*}{280} \\
\hline & $0 \%$ & $1.8 \%$ & $32,1 \%$ & $51,8 \%$ & $14,3 \%$ & $100 \%$ & $75,71 \%$ & \\
\hline \multirow{2}{*}{6} & 0 & 2 & 19 & 26 & 9 & 56 & 210 & \multirow{2}{*}{280} \\
\hline & $0 \%$ & $3,6 \%$ & $33,9 \%$ & $46,4 \%$ & $16,1 \%$ & $100 \%$ & $75 \%$ & \\
\hline \multirow{2}{*}{7} & 1 & 4 & 18 & 28 & 5 & 56 & 200 & \multirow{2}{*}{280} \\
\hline & $1.8 \%$ & $7,1 \%$ & $32,1 \%$ & $50 \%$ & $8,9 \%$ & $100 \%$ & $71,4 \%$ & \\
\hline \multirow{2}{*}{8} & 0 & 4 & 17 & 21 & 14 & 56 & 213 & \multirow{2}{*}{280} \\
\hline & $0 \%$ & $7,1 \%$ & $30,4 \%$ & $37,5 \%$ & $25 \%$ & $100 \%$ & $76,07 \%$ & \\
\hline \multirow{2}{*}{9} & 0 & 2 & 7 & 36 & 11 & 56 & 224 & \multirow{2}{*}{280} \\
\hline & $0 \%$ & $3,6 \%$ & $12,5 \%$ & $64,3 \%$ & $19,6 \%$ & $100 \%$ & $80 \%$ & \\
\hline \multirow{2}{*}{10} & 0 & 2 & 8 & 32 & 14 & 56 & 226 & \multirow{2}{*}{280} \\
\hline & $0 \%$ & $3,6 \%$ & $14,3 \%$ & $57,1 \%$ & $25 \%$ & $100 \%$ & $80,7 \%$ & \\
\hline \multirow{2}{*}{11} & 0 & 3 & 16 & 28 & 9 & 56 & 211 & \multirow{2}{*}{280} \\
\hline & $0 \%$ & $5,4 \%$ & $28,6 \%$ & $50 \%$ & $16,1 \%$ & $100 \%$ & $75,3 \%$ & \\
\hline \multirow{2}{*}{12} & 0 & 2 & 12 & 28 & 14 & 56 & 222 & \multirow{2}{*}{280} \\
\hline & $0 \%$ & $3,6 \%$ & $21,4 \%$ & $50 \%$ & $25 \%$ & $100 \%$ & $79,2 \%$ & \\
\hline \multirow{2}{*}{\multicolumn{7}{|c|}{ Total Skor }} & 2.609 & \multirow{2}{*}{3.360} \\
\hline & & & & & & & $77,64 \%$ & \\
\hline
\end{tabular}

Sumber : Hasil Penelitian, diolah (2020)

Kesimpulan dari tabel analisis statistik deskriptif di atas didapatkan skor total variabel Tindakan Whistleblowing berada pada predikat "Tinggi atau Baik" dengan 
nilai $77,64 \%$, artinya tanggapan responden tinggi terhadap variabel tindakan whistleblowing.

Tabel 4. Tanggapan Responden Terhadap Variabel Komitmen Organisasi

\begin{tabular}{|c|c|c|c|c|c|c|c|c|}
\hline \multirow{2}{*}{$\begin{array}{l}\text { No. } \\
\text { item }\end{array}$} & STS & $\mathrm{TS}$ & $\mathrm{N}$ & $S$ & SS & \multirow{2}{*}{ Jumlah } & Skor & \multirow{2}{*}{$\begin{array}{l}\text { Skor } \\
\text { Ideal }\end{array}$} \\
\hline & 1 & 2 & 3 & 4 & 5 & & Total & \\
\hline \multirow{2}{*}{13} & 1 & 2 & 17 & 24 & 12 & 56 & 212 & \multirow{2}{*}{280} \\
\hline & $1,8 \%$ & $3,6 \%$ & $30,4 \%$ & $42,9 \%$ & $21,4 \%$ & $100 \%$ & $75,71 \%$ & \\
\hline \multirow{2}{*}{14} & 1 & 2 & 13 & 28 & 12 & 56 & 216 & \multirow{2}{*}{280} \\
\hline & $1,8 \%$ & $3,6 \%$ & $23,2 \%$ & $50 \%$ & $21,4 \%$ & $100 \%$ & $77,14 \%$ & \\
\hline \multirow{2}{*}{15} & 2 & 5 & 12 & 27 & 10 & 56 & 206 & \multirow{2}{*}{280} \\
\hline & $3,6 \%$ & $8,9 \%$ & $21,4 \%$ & $48,2 \%$ & $17,9 \%$ & $100 \%$ & $73,57 \%$ & \\
\hline \multirow{2}{*}{16} & 1 & 12 & 19 & 17 & 7 & 56 & 185 & \multirow{2}{*}{280} \\
\hline & $1,8 \%$ & $21,4 \%$ & $33,9 \%$ & $30,4 \%$ & $12,5 \%$ & $100 \%$ & $66,07 \%$ & \\
\hline \multirow{2}{*}{17} & 6 & 15 & 18 & 13 & 4 & 56 & 162 & \multirow{2}{*}{280} \\
\hline & $10,7 \%$ & $26,8 \%$ & $32,1 \%$ & $23,2 \%$ & $7,1 \%$ & $100 \%$ & $57,85 \%$ & \\
\hline \multirow{2}{*}{18} & 1 & 12 & 14 & 23 & 6 & 56 & 189 & \multirow{2}{*}{280} \\
\hline & $1,8 \%$ & $21,4 \%$ & $25 \%$ & $41,1 \%$ & $10,7 \%$ & $100 \%$ & $67,5 \%$ & \\
\hline \multirow{2}{*}{19} & 1 & 5 & 18 & 25 & 7 & 56 & 200 & \multirow{2}{*}{280} \\
\hline & $1,8 \%$ & $8,9 \%$ & $32,1 \%$ & $44,6 \%$ & $12,5 \%$ & $100 \%$ & $71,42 \%$ & \\
\hline \multirow{2}{*}{20} & 3 & 18 & 21 & 10 & 4 & 56 & 162 & \multirow{2}{*}{280} \\
\hline & $5,4 \%$ & $32,1 \%$ & $37,5 \%$ & $17,9 \%$ & $7,1 \%$ & $100 \%$ & $57,85 \%$ & \\
\hline \multirow{2}{*}{21} & 1 & 7 & 25 & 19 & 4 & 56 & 186 & \multirow{2}{*}{280} \\
\hline & $1,8 \%$ & $12,5 \%$ & $44,6 \%$ & $33,9 \%$ & $7,1 \%$ & $100 \%$ & $66,42 \%$ & \\
\hline \multicolumn{7}{|c|}{ Total Skor } & $\frac{1.718}{60.170}$ & 2.520 \\
\hline
\end{tabular}

Sumber : Hasil Penelitian, diolah (2020)

Kesimpulan dari tabel analisis statistik deskriptif di atas didapatkan skor total variabel Komitmen Organisasi berada pada predikat "Tinggi atau Baik" dengan nilai $68,17 \%$, artinya tanggapan responden tinggi terhadap variabel komitmen organisasi.

Tabel 5. Tanggapan Responden Terhadap Variabel Intensitas Moral

\begin{tabular}{|c|c|c|c|c|c|c|c|c|}
\hline \multirow{2}{*}{$\begin{array}{l}\text { No. } \\
\text { item }\end{array}$} & STS & TS & $\mathrm{N}$ & $\mathrm{S}$ & $\mathrm{SS}$ & \multirow{2}{*}{ Jumlah } & $\begin{array}{c}\text { Skor } \\
\text { Total }\end{array}$ & $\begin{array}{c}\text { Skor } \\
\text { Ideal }\end{array}$ \\
\cline { 2 - 8 } 2 & 1 & 2 & 3 & 4 & 5 & & \multirow{2}{*}{280} \\
\cline { 2 - 8 } 22 & $1,8 \%$ & $32,1 \%$ & $28,6 \%$ & $30,4 \%$ & $7,1 \%$ & $100 \%$ & $61,78 \%$ & \\
\hline \multirow{2}{*}{23} & 0 & 2 & 15 & 34 & 5 & 56 & 210 & \multirow{2}{*}{280} \\
\cline { 2 - 8 } & $0 \%$ & $3,6 \%$ & $26,8 \%$ & $60,7 \%$ & $8,9 \%$ & $100 \%$ & $75 \%$ & \\
\hline \multirow{2}{*}{24} & 1 & 8 & 12 & 33 & 2 & 56 & 195 & \multirow{2}{*}{280} \\
\cline { 2 - 8 } & $1,8 \%$ & $14,3 \%$ & $21,4 \%$ & $58,9 \%$ & $3,6 \%$ & $100 \%$ & $69,64 \%$ & \\
\hline \multirow{2}{*}{25} & 0 & 4 & 11 & 32 & 9 & 56 & 182 & \multirow{2}{*}{280} \\
\cline { 2 - 8 } & $0 \%$ & $7,1 \%$ & $19,6 \%$ & $57,1 \%$ & $16,1 \%$ & $100 \%$ & $65 \%$ & \\
\hline
\end{tabular}


Lanjutan Tabel 5. Tanggapan Responden Terhadap Variabel Intensitas Moral

\begin{tabular}{|c|c|c|c|c|c|c|c|c|}
\hline \multirow{2}{*}{$\begin{array}{l}\text { No. } \\
\text { Item }\end{array}$} & STS & TS & $\mathrm{N}$ & $\bar{S}$ & SS & \multirow{2}{*}{ Jumlah } & Skor & \multirow{2}{*}{$\begin{array}{l}\text { Skor } \\
\text { Ideal }\end{array}$} \\
\hline & 1 & 2 & 3 & 4 & 5 & & Total & \\
\hline \multirow{2}{*}{26} & $\overline{0}$ & 2 & 16 & 30 & 8 & 56 & 212 & \multirow{2}{*}{280} \\
\hline & $0 \%$ & $3,6 \%$ & $28,6 \%$ & $53,6 \%$ & $14,3 \%$ & $100 \%$ & $75,71 \%$ & \\
\hline \multicolumn{7}{|c|}{ Total Skor } & 972 & 1.400 \\
\hline
\end{tabular}

Sumber : Hasil Penelitian, diolah (2020)

Kesimpulan dari tabel analisis statistik deskriptif di atas didapatkan skor total variabel Intensitas Moral berada pada predikat "Tinggi atau Baik" dengan nilai 69,4\%, artinya tanggapan responden tinggi terhadap variabel intensitas moral.

Tabel 6. Tanggapan Responden Terhadap Variabel Sosialisasi Antisipatif

\begin{tabular}{|c|c|c|c|c|c|c|c|c|}
\hline \multirow{2}{*}{$\begin{array}{l}\text { No. } \\
\text { item }\end{array}$} & STS & $\mathrm{TS}$ & $\mathrm{N}$ & $\mathrm{S}$ & $\mathrm{SS}$ & \multirow{2}{*}{ Jumlah } & Skor & \multirow{2}{*}{$\begin{array}{l}\text { Skor } \\
\text { Ideal }\end{array}$} \\
\hline & 1 & 2 & 3 & 4 & 5 & & Total & \\
\hline \multirow{2}{*}{27} & 1 & 4 & 11 & 28 & 12 & 56 & 210 & \multirow{2}{*}{280} \\
\hline & $1,8 \%$ & $7,1 \%$ & $19,6 \%$ & $50 \%$ & $21,4 \%$ & $100 \%$ & $75 \%$ & \\
\hline \multirow{2}{*}{28} & 0 & 7 & 16 & 24 & 9 & 56 & 203 & \multirow{2}{*}{280} \\
\hline & $0 \%$ & $12,5 \%$ & $28,6 \%$ & $42,9 \%$ & $16,1 \%$ & $100 \%$ & $72,5 \%$ & \\
\hline \multirow{2}{*}{29} & 3 & 9 & 18 & 23 & 3 & 56 & 182 & \multirow{2}{*}{280} \\
\hline & $5,4 \%$ & $16,1 \%$ & $32,1 \%$ & $41,1 \%$ & $5,4 \%$ & $100 \%$ & $65 \%$ & \\
\hline \multirow{2}{*}{30} & 0 & 2 & 12 & 35 & 7 & 56 & 180 & \multirow{2}{*}{280} \\
\hline & $0 \%$ & $3,6 \%$ & $21,4 \%$ & $62,5 \%$ & $12,5 \%$ & $100 \%$ & $64,28 \%$ & \\
\hline \multirow{2}{*}{31} & 2 & 9 & 24 & 15 & 6 & 56 & 182 & \multirow{2}{*}{280} \\
\hline & $3,6 \%$ & $16,1 \%$ & $42,9 \%$ & $26,8 \%$ & $10,7 \%$ & $100 \%$ & $65 \%$ & \\
\hline \multirow{2}{*}{32} & 1 & 2 & 17 & 28 & 8 & 56 & 208 & \multirow{2}{*}{280} \\
\hline & $1,8 \%$ & $3,6 \%$ & $30,4 \%$ & $50 \%$ & $14,3 \%$ & $100 \%$ & $74,28 \%$ & \\
\hline \multirow{2}{*}{33} & 2 & 9 & 19 & 17 & 9 & 56 & 190 & \multirow{2}{*}{280} \\
\hline & $3,6 \%$ & $16,1 \%$ & $33,9 \%$ & $30,4 \%$ & $16,1 \%$ & $100 \%$ & $67,85 \%$ & \\
\hline \multirow{2}{*}{34} & 2 & 6 & 15 & 25 & 8 & 56 & 199 & \multirow{2}{*}{280} \\
\hline & $3,6 \%$ & $10,7 \%$ & $26,8 \%$ & $44,6 \%$ & $14,3 \%$ & $100 \%$ & $71,07 \%$ & \\
\hline \multirow{2}{*}{35} & 9 & 22 & 13 & 9 & 3 & 56 & 143 & \multirow{2}{*}{280} \\
\hline & $16,1 \%$ & $39,3 \%$ & $23,2 \%$ & $16,1 \%$ & $5,4 \%$ & $100 \%$ & $51,07 \%$ & \\
\hline \multirow{2}{*}{36} & 0 & 12 & 17 & 15 & 12 & 56 & 195 & \multirow{2}{*}{280} \\
\hline & $0 \%$ & $21,4 \%$ & $30,4 \%$ & $26,8 \%$ & $21,4 \%$ & $100 \%$ & $69,64 \%$ & \\
\hline \multirow{2}{*}{37} & 0 & 3 & 17 & 27 & 9 & 56 & 210 & \multirow{2}{*}{280} \\
\hline & $0 \%$ & $5,4 \%$ & $30,4 \%$ & $48,2 \%$ & $16,1 \%$ & $100 \%$ & $75 \%$ & \\
\hline \multicolumn{7}{|c|}{ Total Skor } & $\begin{array}{c}2.102 \\
75.07 \%\end{array}$ & 2.800 \\
\hline
\end{tabular}

Sumber : Hasil Penelitian, diolah (2020)

Kesimpulan dari tabel analisis statistik deskriptif di atas didapatkan skor total variabel Sosialisasi Antisipatif berada pada predikat "Tinggi atau Baik" dengan nilai $75,07 \%$, artinya tanggapan responden tinggi terhadap variabel sosialisasi antisipatif. 


\section{Uji Normalitas}

Tabel 7. One-Sample Kolmogorov-Smirnov Test

\begin{tabular}{|l|l|l|}
\hline \multicolumn{2}{|c|}{} & Unstandardized Residual \\
\hline $\mathbf{N}$ & Mean & 56 \\
\hline Normal & Parameters & a,b \\
\cline { 2 - 3 } & Std. Deviation & .0000000 \\
\hline Most & Absolute & 4.60681737 \\
\cline { 2 - 3 } $\begin{array}{l}\text { Extreme } \\
\text { Differences }\end{array}$ & Positive & .088 \\
\cline { 2 - 3 } & Negative & .077 \\
\hline Test Statistic & -.088 \\
\hline Asymp. Sig. (2-tailed) & .088 \\
\hline
\end{tabular}

Sumber : Hasil Penelitian, diolah (2020)

Dari tabel uji normalitas diatas dapat dilihat output dari uji normalitas yang dilakukan penulis menunjukan hasil dengan signifikansi (Sig.) 0.200 yang artinya nilai signifikansi lebih besar dari $a=0.05$ (Sig. $0.200>a=0.05$ ). Dengan demikian, berdasarkan taraf signifikansi menunjukan bahwa data yang digunakan pada penelitian ini terdistribusi normal.

\section{Uji Multikolinearitas}

Tabel 8. Uji Multikolinearitas Dengan Matrik Korelasi

\begin{tabular}{|l|l|l|l|l|l|}
\hline \multicolumn{2}{|l|}{ Model } & Total X3 & Total X2 & Total X1 \\
\hline 1 & Correlations & Total X3 & 1.000 & -.302 & -.306 \\
\cline { 3 - 6 } & Total X2 & -.302 & 1.000 & -.210 \\
\cline { 3 - 6 } & Total X1 & -.306 & -.210 & 1.000 \\
\cline { 3 - 6 } & \multirow{4}{*}{ Covariances } & Total X3 & .018 & -.011 & -.005 \\
\cline { 3 - 6 } & Total X2 & -.011 & .079 & -.008 \\
\hline & Total X1 & -.005 & -.008 & .017 \\
\hline
\end{tabular}

Sumber : Hasil Penelitian, diolah (2020)

Pada tabel uji multikolinearitas dengan matrik korelasi di atas dapat dilihat bahwa matrik korelasi antar variabel bebas (independen) adalah sebesar -0.306 atau sebesar $30.6 \%$, karena nilai korelasi masih di bawah 95\% maka dapat dikatakan tidak terjadi multikolinearitas. 


\section{Uji Heteroskedastisitas}

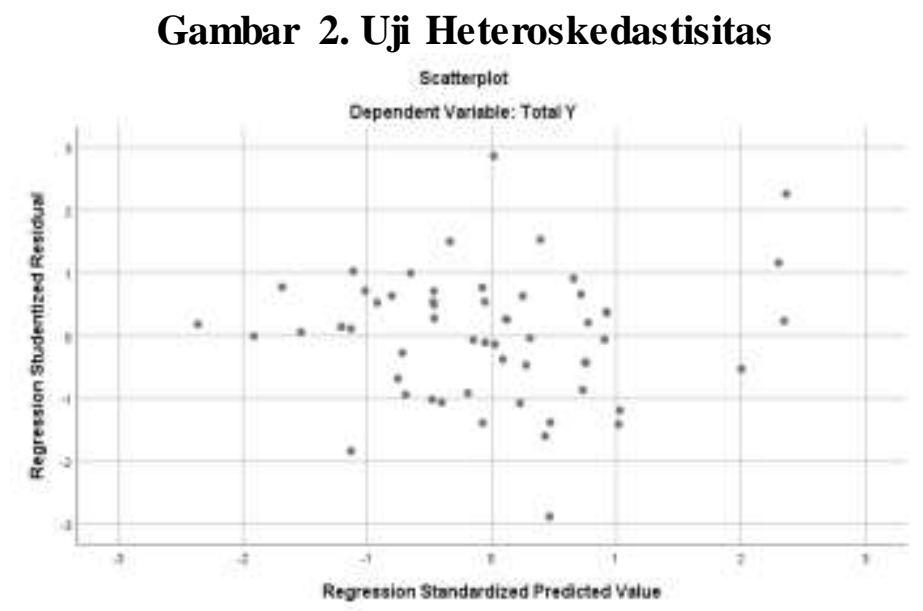

Sumber : Hasil Penelitian, diolah (2020)

Berdasarkan hasil uji heteroskedastisitas diatas diketahui bahwa :

1. Titik-titik data menyebar diatas dan dibawah atau disekitar angka 0 .

2. Titik-titik tidak mengumpul hanya diatas atau dibawah.

3. Penyebaran titik-titik tidak membentuk pola atau gelombang melebar kemudian menyempit dan melebar kembali.

4. Penyebaran titik-titik tidak membentuk pola tertentu atau tidak berpola.

Dengan demikian maka dapat ditarik kesimpulan bahwa tidak terjadi masalah heteroskedastisitas pada hasil gambar di atas, yang berarti model regresi yang baik dapat terpenuhi.

\section{Uji Analisis Regresi Linier Berganda}

Tabel 8. Hasil Uji Regresi Linier Berganda

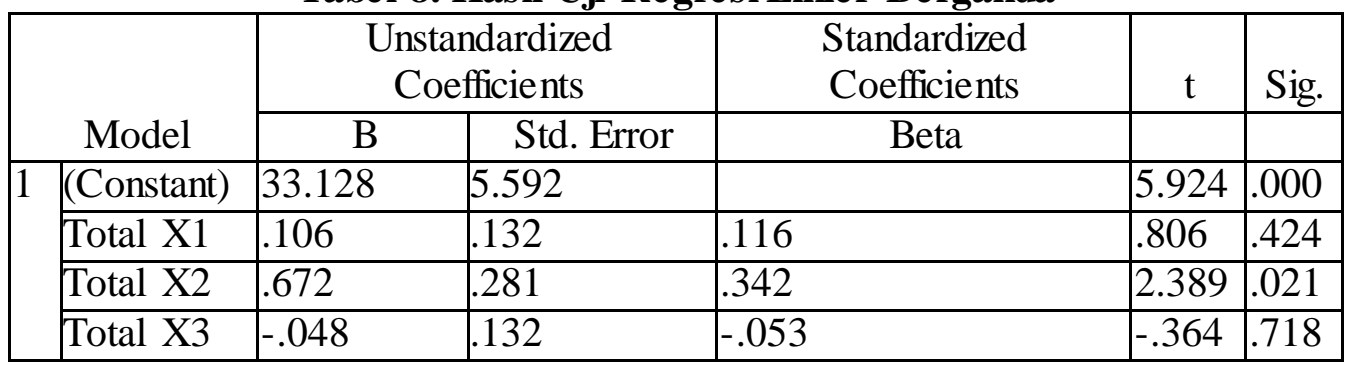

Sumber : Hasil Penelitian, diolah (2020)

Berdasarkan hasil dari regresi linier berganda yang ada pada tabel diatas, maka disusunlah model regresi sebagai berikut:

$$
\begin{aligned}
& Y^{\prime}=a+b_{1} x_{1}+b_{2} x_{2}+b_{3} x_{3}+e \\
& Y^{\prime}=33.128+0.106 x_{1}+0.672 x_{2}-0.048 x_{3}+e
\end{aligned}
$$

Keterangan :

$$
\begin{array}{ll}
Y^{s}=\text { Tindakan Whistleblowing } & x_{3}=\text { Sosialisasi antisipatif } \\
x_{1}=\text { Komitmen Organisasi } & e=\text { Standard error } \\
x_{2}=\text { Intensitas Moral } &
\end{array}
$$


Model persamaan regresi linier berganda tersebut artinya :

1. Pada tabel constanta menunjukan apabila tidak terdapat komitmen organisasi, intensitas moral, dan sosialisasi antisipatif maka alumni S1 Akuntansi Telkom University yang lulus pada tahun 2017-2019 akan melakukan tindakan whistleblowing sebesar 33,128.

2. Variabel komitmen organisasi sbesar 0,106 menunjukkan bahwa setiap terjadinya peningkatan sebesar $1 \%$ komitmen organisasi maka tindakan whistleblowing alumni S1 Akuntansi Telkom University yang lulus pada tahun 2017-2019 akan meningkat sebesar $1.06 \%$.

3. Variabel intensitas moral sbesar 0,672 menunjukkan bahwa setiap terjadinya peningkatan sebesar $1 \%$ intensitas moral dengan maka tindakan whistleblowing alumni S1 Akuntansi Telkom University yang lulus pada tahun 2017-2019 akan meningkat sebesar $6,72 \%$.

4. Variabel Sosialisasi Antisipatif sbesar -0,048 menunjukkan bahwa setiap terjadinya peningkatan sebesar $1 \%$ sosialisasi antisipatif maka tindakan whistleblowing alumni S1 Akuntansi Telkom University yang lulus pada tahun 2017-2019 akan menurun sebesar $0,48 \%$.

\section{Uji Analisis Koefisien Korelasi}

Tabel 9. Uji Analisis Koefisien Korelasi

\begin{tabular}{|l|l|l|l|l|l|}
\hline \multicolumn{2}{|c|}{} & Total Y & Total X1 & Total X2 & Total X3 \\
\hline \multirow{2}{*}{$\begin{array}{l}\text { Total } \\
\text { Y }\end{array}$} & Pearson Correlation & 1 & .208 & $.359^{* *}$ & .127 \\
\cline { 2 - 6 } & Sig. (2-tailed) & & .123 & .007 & .351 \\
\cline { 2 - 6 } & $\mathrm{N}$ & 56 & 56 & 56 & 56 \\
\hline \multirow{2}{*}{$\begin{array}{l}\text { Total } \\
\text { X1 }\end{array}$} & Pearson Correlation & .208 & 1 & $.334^{*}$ & $.397^{* *}$ \\
\cline { 2 - 6 } & Sig. (2-tailed) & .123 & & .012 & .002 \\
\cline { 2 - 6 } & $\mathrm{N}$ & 56 & 56 & 56 & 56 \\
\hline \multirow{2}{*}{$\begin{array}{l}\text { Total } \\
\text { X2 }\end{array}$} & Pearson Correlation & $.359^{* *}$ & $.334^{*}$ & 1 & $.394^{* *}$ \\
\cline { 2 - 6 } & Sig. (2-tailed) & .007 & .012 & & .003 \\
\cline { 2 - 6 } & $\mathrm{N}$ & 56 & 56 & 56 & 56 \\
\hline Total & Pearson Correlation & .127 & $.397^{* *}$ & $.394^{* *}$ & 1 \\
\cline { 2 - 6 } X3 & Sig. (2-tailed) & .351 & .002 & .003 & \\
\cline { 2 - 6 } & $\mathrm{N}$ & 56 & 56 & 56 & 56 \\
\hline
\end{tabular}

Sumber : Hasil Penelitian, diolah (2020)

1. Kemudian jika dilihat dari hubungan kekuatan antara variabel X1 (Komitmen Organisasi) dengan variabel Y (Tindakan Whistleblowing) memiliki tingkat korelasi bersifat positif dengan predikat rendah dikarnakan nilai dari Pearson Correlation (r) $=0.208$ dengan interval koefisien diantara $0.20-0.399$ (rendah).

2. Lalu pada variabel X2 (Intensitas Moral) dengan variabel Y (Tindakan Whistleblowing) memiliki tingkat korelasi bersifat positif dengan predikat rendah dikarnakan nilai dari Pearson Correlation ( $r)=0.359$ dengan interval koefisien diantara 0.20 - 0.399 (rendah). 
3. Selanjutnya pada variabel X3 (Sosialisasi Antisipatif) dengan variabel Y (Tindakan Whistleblowing) memiliki tingkat korelasi bersifat positif dengan predikat sangat rendah dikarnakan nilai dari Pearson Correlation $(r)=0.127$ dengan interval koefisien diantara $0.00-0.199$ (sangat rendah).

\section{Uji Koefisien Determinasi Berganda $\left(\mathbf{R}^{2}\right)$}

Tabel 10. Uji Koefisien Determinasi Berganda $\left(\mathbf{R}^{2}\right)$

\begin{tabular}{|l|l|l|l|l|}
\hline Model & $\mathrm{R}$ & R Square & $\begin{array}{l}\text { Adjusted } \\
\text { Square }\end{array}$ & $\begin{array}{l}\text { Rtd. Error of the } \\
\text { Estimate }\end{array}$ \\
\hline 1 & $.374^{\mathrm{a}}$ & .140 & .091 & 4.738 \\
\hline
\end{tabular}

Sumber : Hasil Penelitian, diolah (2020)

Dari tabel Uji Koefisien Determinasi Berganda $\left(\mathrm{R}^{2}\right)$ diatas menunjukan nilai koefisien determinasi ( $\mathrm{R}$ Square) sebesar 0.140 atau sama dengan 14.0\%, angka terssebut mengandung arti bahwa variabel X1 (Komitmen Organisasi), X2 (Intensitas Moral) dan X3 (Sosialisasi Antisipatif) secara simultan (bersama-sama) berpengaruh terhadap variabel $\mathrm{Y}$ (Tindakan Whistleblowing) sebesar $14.0 \%$ sedangakan sisanya dipengaruhi oleh variabel lain di luar persamaan regresi ini.

Uji Simultan (F)

Tabel 11. Hasil Uji Statistik (F)

\begin{tabular}{|c|c|c|c|c|c|c|}
\hline Model & & \begin{tabular}{|l} 
Sum \\
Squares
\end{tabular} & df & $\begin{array}{l}\text { Mean } \\
\text { Square }\end{array}$ & $\mathrm{F}$ & Sig. \\
\hline \multirow[t]{3}{*}{1} & Regression & 190.301 & 3 & 63.434 & 2.826 & $.048^{b}$ \\
\hline & Residual & 1167.252 & 52 & 22.447 & & \\
\hline & Total & 1357.554 & 55 & & & \\
\hline
\end{tabular}

Sumber : Hasil Penelitian, diolah (2020)

Berdasarkan tabel hasil Uji Statistik (F) yang telah dilakukan penulis diatas didapatkan $\mathrm{F}$ hitung $2.826>\mathrm{F}$ tabel 2.78 dan berdasarkan nilai signifikansi (Sig.) $0.048<0.05$. Dengan demikian didapatkan hipotesis yaitu H0 ditolak dan Ha diterima yang artinya variabel independen berpengaruh secara simultan terhadap variabel dependen.

\section{Uji Parsial (T)}

Tabel 12. Hasil Uji Parsial (T)

\begin{tabular}{|c|c|c|c|c|c|c|}
\hline \multirow{2}{*}{\multicolumn{2}{|c|}{ Model }} & \multicolumn{2}{|c|}{$\begin{array}{l}\text { Unstandardized } \\
\text { Coefficients }\end{array}$} & \multirow{2}{*}{$\begin{array}{l}\text { Standardized } \\
\text { Coefficients } \\
\text { Beta }\end{array}$} & \multirow[b]{2}{*}{ t } & \multirow[b]{2}{*}{ Sig. } \\
\hline & & $\mathrm{B}$ & Std. Error & & & \\
\hline \multirow[t]{4}{*}{1} & (Constant) & 33.128 & 5.592 & & 5.924 & .000 \\
\hline & Total X1 & .106 & .132 & .116 & .806 & .424 \\
\hline & Total X2 & .672 & .281 & .342 & 2.389 & .021 \\
\hline & Total X3 & -.048 & .132 & -.053 & -.364 & .718 \\
\hline
\end{tabular}

Sumber : Hasil Penelitian, diolah (2020)

Pada tabel hasil Uji Parsial $(\mathrm{T})$ di atas, terilihat berdasarkan $\mathrm{t}$ hitung dengan $\mathrm{t}$ tabel pada variabel komitmen organisasi bahwa nilai $\mathrm{t}$ hitung adalah $0.806<\mathrm{t}$ tabel 
2.00575 dan berdasarkan nilai signifikansinya yaitu $0.424>0.05$. Dengan demikian didapatkan hasil yaitu variabel komitmen organisasi secara parsial tidak memiliki pengaruh terhadap variabel tindakan whistleblowing ( $\mathrm{H} 0$ diterima dan Ha ditolak).

Kemudian pada variabel intensitas moral bahwa nilai t hitung adalah $2.389>\mathrm{t}$ tabel 2.00575 dan berdasarkan nilai signifikansinya yaitu $0.021>0.05$. Dengan demikian didapatkan hasil yaitu variabel intensitas moral secara parsial memiliki pengaruh terhadap variabel tindakan whistleblowing ( $\mathrm{H} 0$ ditolak dan Ha diterima).

Selanjutnya pada variabel sosialisasi antisipatif bahwa nilai $\mathrm{t}$ hitung adalah $0.364<\mathrm{t}$ tabel 2.00575 dan berdasarkan nilai signifikansinya yaitu $0.718>0.05$. Dengan demikian didapatkan hasil yaitu variabel sosialisasi antisipatif secara parsial tidak memiliki pengaruh terhadap variabel tindakan whistleblowing (H0 diterima dan Ha ditolak).

\section{KESIMPULAN DAN SARAN \\ Kesimpulan}

Penelitian ini bertujuan mengetahui pengaruh komitmen organisasi, intensitas moral, dan sosialisasi antisipatif terhadap tindakan whistleblowing. Sampel yang digunakan dalam penelitian ini terdiri dari 56 orang alumni S1 Akuntansi Telkom University yang lulus pada tahun 2017-2019. Berdasarkan pengujian hipotesis secara simultan menunjukkan hasil bahwa variabel komitmen organisasi, intensitas moral, dan sosialisasi antisipatif berpengaruh secara simultan terhadap variabel tindakan whistleblowing pada alumni S1 Akuntansi Telkom University yang lulus pada tahun 2017-2019.

Berdasarkan pengujian secara parsial yaitu variabel komitmen organisasi, intensitas moral, dan sosialisasi antisipatif terhadap tindakan whistleblowing adalah sebagai berikut :

1. Komitmen organisasi tidak berpengaruh secara parsial terhadap tindakan whistleblowing pada alumni S1 Akuntansi Telkom University yang lulus pada tahun 2017-2019.

2. Intensitas moral berpengaruh secara parsia dengan terhadap tindakan whistleblowing pada alumni S1 Akuntansi Telkom University yang lulus pada tahun 2017-2019.

3. Sosialisasi antisipatif tidak berpengaruh secara parsial terhadap tindakan whistleblowing pada alumni S1 Akuntansi Telkom University yang lulus pada tahun 2017-2019.

\section{Saran}

1. Bagi para akademisi, dalam penelitian ini penulis berharap dapat memberikan tambahan pengetahuan dan wawasan dalam bidang Ilmu Akuntansi khususnya dalam bidang audit.

2. Bagi peneliti selanjutnya, penulis berharap dapat dijadikan rujukan dalam penelitian tentang persepsi akuntan dengan fokus pada niat melakukan tindakan whistleblowing, serta diharapkan menambah wawasan dan pengetahuan tentang whistleblowing. 
3. Bagi akuntan atau karyawan diharapkan memberi wawasan, ilmu dan pengetahuan mengenai tindakan whistleblowing yang dapat menjadi alat pelaporan kecurangan yang efektif dan efisien dalam pengungkapan kecurangan yang merugikan perusahaan ataupun merugikan karyawan sendiri.

4. Bagi perusahaan berdasarkan hasil penelitian, intensitas moral memiliki pengaruh terhadap tindakan whistleblowing, oleh karena itu perusahaan diharapkan memberikan pendidikan dan pelatihan moral kepada karyawan baik melalui pelatihan anti kecurangan dan pengenalan whistleblowing hotline.

\section{DAFTAR PUSTAKA}

ACFE. 2016. Survai Fraud Indonesia. Dalam A. o. Examiners, Survai Fraud Indonesia 2016. Jakarta: ACFE Indonesia Chapter.

Bakri. 2014. Analisis Komitmen Profesional dan Sosialisasi Antisipatif Serta Hubungannya dengan Whistleblowing. Jurnal Al-Mizan, Vol.10, No. 1.

Gani, R. M. 2010. Analisis Perbedaan Komitmen Profesional dan Sosialisasi Antisipatif Mahasiswa PPA dan non-PPA pada Hubungannya Dengan Whistleblowing. Skripsi. Fakultas Ekonomi Universitas Diponegoro. Semarang. Tidak di terbitkan.

Kreshastuti, D. K. 2014. Analisis faktor-faktor yang mempengaruhi intensi auditor untuk melakukan tindakan whistleblowing. DIPONEGORO JOURNAL OF ACCOUNTING, 1-15.

Setiawati, L. P. 2016. Profesionalisme, komitmen organisasi, intensitas moral, dan tindakan akuntan melakukan whistleblowing. E-Jurnal Akuntansi Universitas Udayana Vol.17.1, 257-282.

Sofyanty, D. 2019. Pengaruh Komitmen Organisasi dan Iklim Organisasi Terhadap Tindakan WhistleBlowing. widyacipta, 43-50.

Sugianto, A. H. 2011. Hubungan Orientasi Etika, Komitmen Profesional, Sensitivitas Etis dengan Whistleblowing Perspektif Mahasiswa Akuntansi. Tesis. Fakultas Ekonomi Universitas Diponegoro. Semarang. 